\title{
Emergence of Reading and Writing in Illiterate Adults After Matching-to-Sample Tasks ${ }^{1}$
}

\author{
Carmen Silvia Motta Bandini² \\ Universidade Estadual de Ciências da Saúde de Alagoas, Maceió-AL, Brazil \\ Centro Universitário CESMAC, Maceió-AL, Brazil \\ Heloisa Helena Motta Bandini \\ Universidade Estadual de Ciências da Saúde de Alagoas, Maceió-AL, Brazil \\ Ana Carolina Sella \\ University of Nebraska Medical Center, Omaha-NE, United States of America \\ Deisy das Graças de Souza \\ Universidade Federal de São Carlos, São Carlos-SP, Brazil
}

\begin{abstract}
Reading and writing are behaviors that provide an individual with the opportunity for inclusion in many social environments. Despite the importance of these behaviors, statistical indices show that, in Brazil, 8.6\% of the people aged 15-24 are illiterate. The purpose of this manuscript, which is divided into two studies, was to assess the effects of a Portuguese language reading curriculum for simple (Study 1) and complex words (Study 2) in illiterate adults. Four participants took part in each study. In both studies, reading was taught mainly by training dictated words to printed words relations. Overall, there was an increase in the percentage of correct responses in reading and writing tasks when pre-tests and post-tests were compared; results were more consistent in reading tasks. Future studies should continue to investigate procedures with these goals for this population.
\end{abstract}

Keywords: reading, handwriting, adults

\section{Emergência de Leitura e Escrita em Adultos Analfabetos Após Tarefas de Matching- to-Sample}

\begin{abstract}
Resumo: Ler e escrever são comportamentos que proporcionam a inserção dos indivíduos em grande parte dos ambientes sociais. Apesar de sua importância, índices mostram que, no Brasil, 8,6\% das pessoas com idades entre 15 e 24 anos são analfabetas. O presente artigo, dividido em dois estudos, teve como objetivo avaliar os efeitos de um currículo de ensino de leitura de palavras simples (Estudo 1) e de palavras complexas (Estudo 2) da língua portuguesa para adultos analfabetos. Cada estudo teve quatro participantes. Em ambos os estudos a leitura foi ensinada primordialmente pelo treino de relações entre palavras ditadas e palavras impressas. De forma geral, houve aumento na porcentagem de acertos em leitura e em escrita manuscrita quando comparados os desempenhos do pré-teste e dos demais testes, sendo os resultados mais consistentes nas tarefas de leitura. Estudos futuros devem continuar as investigações acerca de procedimentos com estes objetivos para esta população.
\end{abstract}

Palavras-chave: leitura, escrita, adultos

\section{Emergencia de Lectura y Escritura en Adultos Analfabetos Después de Tareas de Igualación de la Muestra}

\begin{abstract}
Resumen: Leer y escribir son comportamientos que proporcionan la inclusión de los individuos en una gran parte de los entornos sociales. A pesar de su importancia, los índices muestran que, en Brasil, el 8,6\% de las personas de edades comprendidas entre 15 y 24 años es analfabeto. El objetivo de este trabajo, divido en dos estudios, fue examinar los efectos de un currículo para la enseñanza de la lectura de palabras simples (Estudio 1) y palabras complejas (Estudio 2) de la lengua portuguesa para adultos analfabetos. Cada estudio tuvo cuatro participantes. En ambos estudios, la lectura se enseñó principalmente a través de relaciones entre palabras dictadas y palabras impresas. En general, hubo un aumento en el porcentaje de respuestas correctas en actividades de lectura y escritura al comparar las pruebas de antes y después del estudio; los resultados fueron más consistentes en las actividades de lectura que en las de escritura. Investigaciones futuras pueden aportar a la investigación sobre procedimientos con estos objetivos para esta población.
\end{abstract}

Palabras clave: lectura, escritura manual, adulto

According to the National Household Sample Survey of the Brazilian Institute of Geography and Statistics (IBGE, 2011), in 2011 the illiteracy rate in Brazil was $8.6 \%$ among people

\footnotetext{
1 Acknowledgment: Jackson Ítalo Tavares da Rocha. Support: National Council for Scientific and Technological Development (CNPq) - Grant \# 573972/2008, São Paulo Research Foundation (FAPESP) Grant \# 2008/57705-8.

2 Correspondence address:

Carmen Silvia Motta Bandini. Rua Jorge de Lima, 113, Trapiche da Barra. CEP 57010-382. Maceió-AL, Brazil. E-mail: csmbandini@gmail.com
}

between 15 and 24 years of age. These numbers, although still considered high by the United Nations Educational, Scientific and Cultural Organization (UNESCO, 2011), were even more worrying in the past: $72 \%$ in 1920 (Strelhow, 2010) and 20\% in 1991 (Paiva, Machado, \& Ireland, 2007).

The pursuit of a decrease in illiteracy rates among adults in Brazil has led to the development of several programs with different pedagogical and methodological concepts for the education of youths and adults over the past 70 years (Amparo, 2012; Di Pierro, Joia, \& Ribeiro, 
2001; Strelhow, 2010). However, according to Amparo (2012) and Di Pierro et al. (2001), the conceptual and critical framework of these movements toward literacy for adults in Brazil only occurred because of the work of Paulo Freire in the 1960s and 1970s. The Brazilian Literacy Movement (MOBRAL), the Solidarity Literacy Program and currently the Literate Brazil Program, which includes actions such as the National Youth Inclusion Program: Community Education, Qualification and Action (Projovem and Projovem-Urbano), and the classes of Education for Youth and Adults (EJA) are examples of such programs.

Despite advances in the education of youths and adults in Brazil and the reduction of illiteracy rates from 1920 to current levels, the still large number of illiterate people at productive age has generated discussions that indicate factors which could lead to improvements in the current programs, such as the EJAs. Three points are recurrently discussed in the Education literature (Andrade, Esteves, \& Oliveira, 2009; Arroyo, 2007; Friedrich, Benite, Benite, \& Pereira, 2010; Muenchen \& Auler, 2007; Ribeiro, 2006; Soares, 2008; Strelhow, 2010): (a) the need for the curricula and teacher-student communication not to be fragmented and the experiences of the students throughout their lives to be incorporated into the courses, (b) the access and dropout rates of the current youth and adult literacy programs, and (c) insufficient results, especially regarding the acquisition of reading with comprehension and cursive writing.

Regarding the first point, Muenchen and Auler (2007) and Oliveira (2007) commented that it is common that teaching and the communication between young people and their teachers are restricted to the formal content of the curricula. According to these authors, the teachers seek to explain the contents to the students, usually starting from their own point of view, without taking into consideration that youth and adults have had life histories and experiences prior to returning to the school. Thus, there is no dialogue between knowledge provided in the classroom and the desires and expectations of the students for whom this knowledge is intended.

Regarding the second item, access and dropout rates of the students, Gentili (2003) states that the number of students enrolled in the EJAs throughout Brazil is unsatisfactory: of the 68 million of Brazilian youth and adults, aged 15 years and over that have not completed elementary education, only six million (i.e. $8.8 \%$ of the total) are enrolled in EJAs. Regarding dropout rates, this author showed that less than $30 \%$ of the students who go back to school after the age of 15 do complete their courses. Muenchen and Auler (2007) consider that these dropout rates may be related to several factors such as: use of incorrect material for the age group (Amparo, 2012; Oliveira, 2007), content with little connection to the everyday life of the students (Oliveira, 2007), teachers unprepared to work with this population (Soares, 2008), and even class schedules that do not conform to the possibilities of the people who work and study at the same time.
Finally, in relation to the third item mentioned, the insufficient results in the acquisition of reading and writing, Ribeiro (2006) points out that it must be recognized that the results of the education of students participating in EJAs and other programs are insufficient in terms of learning. This poor performance, according to the author, prevents better results in other skills, as satisfactory performance in any discipline depends on reading written material with comprehension and creating written text. Thus, Ribeiro (2006) indicates that it is necessary for educators to act in a coordinated way to promote these skills, with clear teaching strategies, planning of the desirable progression stages throughout the process, and constant monitoring of the educational process.

Several areas of knowledge can contribute to the resolution of each one of these items. Specifically in relation to the third item discussed (insufficient results), Behavior Analysis has a body of knowledge regarding effective methods for teaching language skills accumulated since the 1960s. This aspect of research is based on the assumptions presented by Skinner (1957) and on Sidman's studies published since 1971. According to Skinner, reading and writing, as well as other verbal operants, should be comprehended as functionally independent, which implies that the learning of one does not necessarily entails learning the other.

An example of a teaching curriculum based on Behavior Analysis, which has been used with different populations and has shown good results is the Learning to read and write in small steps curriculum, developed by Rosa-Filho, de Rose, de Souza, Hanna and Fonseca (1998) for individual application, in both a printed version (de Rose, de Souza, \& Hanna, 1996; de Souza \& de Rose, 2006), and a computerized version (de Souza et al., 2009; Rosa Filho et al., 1998). The initial module of this curriculum focuses on teaching simple words, with consonant-vowel sequences, and was experimentally applied with children with learning disabilities (de Rose et al., 1996, de Souza et al., 2009; Reis, de Souza, \& de Rose, 2009), deaf children using hearing aids (França, Bandini, \& Bandini, 2011), preschool children (Melchiori, de Souza, $\&$ de Rose, 2000), individuals with intellectual disabilities (Alves, Kato, Assis, \& Maranhão, 2007; Melchiori et al., 2000) and illiterate adults (Medeiros, Monteiro, \& Silva, 1997; Melchiori et al., 2000). The second module of the curriculum aims at teaching complex words, with sequences that encompass consonant clusters (irregular syllables) and was also applied to children with learning difficulties (de Souza, de Rose, Fonseca, \& Hanna, 1999) and illiterate adults (Medeiros et al., 1997).

Despite the functional independence of the verbal operants, some studies have demonstrated that these behaviors may be related in the repertoire of an individual who is literate and fluent in reading and writing. The studies performed by Sidman (1994), for example, suggest that the different operants involved in what is generically called reading (textual behavior) and writing (copying and 
dictation) can form a network of relationships between stimuli and between stimuli and responses.

Subsequent studies incorporated new tasks into Sidman's procedure (1994), adding new findings to the initial ones. Studies such as those of de Rose et al. (1996), Hanna, de Souza, de Rose and Fonseca (2004), Hübner, Gomes and McIlvane (2009) and Stromer, Mackay, Howell, McVay and Flusser (1996), for example, used word construction tasks from individual sample letters (constructed-response matching-to-sample [CRMTS]) (Dube, McDonald, McIlvane, \& Mackay, 1991; Stromer \& Mackay, 1992) during training trials and found that these favored the emergence of generalized reading and writing. Furthermore, de Souza, de Rose and Domeniconi (2009), Reis et al. (2009) and Sella, Bandini, Oliveira and Bandini (2010) incorporated the teaching of relationships between dictated syllables and printed syllables that compose the words with copying with CRMTS (Reis et al., 2009) or dictation with CRMTS (Sella et al., 2010) tasks. The results showed a significant increase in the performance of the participants in reading and dictated writing. However, in the case of writing, despite the improvement in relation to the initial performance, this effect was still variable, replicating the lack of systematic effects described in previous studies.

The studies developed from Learning to read and write in small steps have generated a solid body of empirical findings documenting the emergence of writing repertoires derived from teaching reading repertoires. However, despite the effectiveness of the curriculum with many populations there are few reports of studies in Behavior Analysis investigating the emergence of reading and writing with illiterate adults. Medeiros et al. (1997) and Melchiori et al. (2000) may be used as examples.

Medeiros et al. (1997) conducted a study with an illiterate woman aged 37 years and used a procedure to teach her how to read 33 Portuguese words, which were part of the verbal universe of the participant. The target words could be simple (regular words) or complex (irregular words). New words formed by recombining the syllables of the target words were tested. The procedure was mainly composed of tasks that related printed and dictated words. An interview was conducted to collect the opinion of the participant regarding the mode of teaching and her learning. The results indicated that the participant learned to read the target words and showed generalization of this behavior, although at lower rates, for the new words tested. According to the interview, this generalization was also obtained for contexts external to that of teaching. It was also found that the reading of the simple words had higher scores $(100 \%$ correct responses) than the reading of the complex words ( $90 \%$ correct responses).

Melchiori et al. (2000) taught eight illiterate adult women, 40 to 65 years of age, who had either never attended school or attended it for less than six months, to read 51 simple Portuguese words. The results were similar to those reported in the study by Medeiros et al. (1997), showing that all the participants learned to read the target words and at least six of the participants could correctly read half or more of the new words tested.

The present study was developed considering: (a) the number of adults who could benefit from the effective teaching of reading and writing skills; (b) the lack of Behavior Analytic studies and programs directed toward teaching these repertoires to this population; (c) the importance of comprehending the variables involved in learning to read and write for illiterate adults; (d) the importance of investigating the possible dependence relations between reading and writing repertoires in this population; and (e) the importance of consistency between the knowledge of Behavior Analysis and the knowledge already produced by the Education area regarding methods of teaching youth and adults. Divided into two studies, this paper aimed to evaluate, in Study 1, the effects of Module 1 (simple and regular words), and, in Study 2, the effects of Module 2 (complex and irregular words) of the Learning to read and write in small steps curriculum (de Rose et al., 1996, de Souza et al., 2009) in its computerized version (Rosa Filho et al., 1998) on reading and writing behaviors in two groups of illiterate adults.

This article differs from the studies of Medeiros et al. (1997) and Melchiori et al. (2000) in some important aspects. First, in this article there is a detailed analysis of the performance of the participants in emergent writing tests, which were not performed in the other studies. These analyses can reveal whether learning on the computer could be useful in a new context, considering that writing is an important form of communication for adults. Second, unlike the study of Medeiros et al., in this article the training of simple words was separated from the training of complex words, following the tradition of the studies with the Learning to read and write in small steps curriculum (Rosa Filho et al., 1998). The intention was to maintain performance at $100 \%$ accuracy in both types of words.

\section{Method - Study 1}

\section{Participants}

One man and three women, aged between 17 years and 64 years and 5 months at the beginning of the study, participated in Study 1. Two were students at a public school in state of Alagoas, students of the EJA program, and two attended a research center at a public state university in the same state. All had performances between $0 \%$ (zero percent) and $20 \%$ (twenty percent) of correct responding in the General Reading Pre-Test (Table 1).

\section{Instruments}

Module 1 of the computerized curriculum Learning to read and write in small steps (Rosa Filho et al., 1998) was used for the data collection. Part of the data collection was conducted in the research center and occurred in a room 
Table 1

Characterization of the Participants of Study 1, by Gender, Age, Performance in Reading and Writing of Whole Words in the Pre-Test, and Location of Data Collection

\begin{tabular}{lccccc}
\hline Participants & Gender & Age & $\begin{array}{c}\text { \% of Correct Reading } \\
\text { Responses }\end{array}$ & $\begin{array}{c}\text { \% of Correct Writing } \\
\text { Responses }\end{array}$ & $\begin{array}{c}\text { Place of Data } \\
\text { Collection }\end{array}$ \\
\hline P1 & $\mathrm{F}$ & 45 years and 4 months & 13.3 & 0 & EJA \\
P2 & $\mathrm{F}$ & 17 years & 20 & 0 & EJA \\
P3 & $\mathrm{M}$ & 34 years and 8 months & 20 & 53.3 & Center \\
P4 & $\mathrm{F}$ & 64 years and 5 months & 0 & 0 & Center \\
\hline
\end{tabular}

equipped with four computers with headphones through which the participants listened to the instructions presented by the teaching program. The other part of the data collection was performed in the school that the first two participants attended and took place in a quiet room provided by the school, with one computer that had two speakers.

\section{Procedure}

Table 2

Steps of Teaching Modules 1 and 2 of the 'Learning to Read and Write in Small Steps' Curriculum

\begin{tabular}{|c|c|c|c|c|}
\hline & \multicolumn{4}{|c|}{ Steps of the Procedure } \\
\hline & General Pre-Test & Teaching & Unit Post-Test & General Post-Test \\
\hline \multirow[t]{2}{*}{$\begin{array}{l}\text { Study } 1 \\
\text { Module } 1 \\
\text { (simple words) }\end{array}$} & $\begin{array}{l}\text { (a) Reading test with } 15 \\
\text { words (computerized) }\end{array}$ & $\begin{array}{l}\text { (a) Matching-to-sample } \\
\text { trials interspersed with } \\
\text { dictation-CRMTS trials } \\
\text { (computerized) }\end{array}$ & $\begin{array}{l}\text { (a) Reading words of the } \\
\text { unit test (computerized) }\end{array}$ & $\begin{array}{l}\text { (a) Reading test with } 76 \\
\text { words (computerized) }\end{array}$ \\
\hline & $\begin{array}{l}\text { (b) Writing test with } 15 \\
\text { words (computerized) }\end{array}$ & $\begin{array}{l}\text { (b) Syllabic Training } \\
\text { (computerized) }\end{array}$ & $\begin{array}{l}\text { (b) Writing words of the } \\
\text { unit test (not computerized) }\end{array}$ & $\begin{array}{l}\text { (b) Writing test with } 20 \\
\text { words (computerized) }\end{array}$ \\
\hline \multirow[t]{2}{*}{$\begin{array}{l}\text { Study } 2 \\
\text { Module } 2 \\
\text { (complex words) }\end{array}$} & $\begin{array}{l}\text { (a) Reading test with } 25 \\
\text { words (computerized) }\end{array}$ & $\begin{array}{l}\text { (a) Matching-to-sample } \\
\text { trials interspersed with } \\
\text { dictation-CRMTS trials } \\
\text { (computerized) }\end{array}$ & $\begin{array}{l}\text { (a) Reading words of the } \\
\text { unit test (computerized) }\end{array}$ & $\mathrm{N} / \mathrm{A}$ \\
\hline & $\begin{array}{l}\text { (b) Writing test with } 25 \\
\text { words (computerized) }\end{array}$ & & $\begin{array}{l}\text { (b) Writing words of the } \\
\text { unit test (not computerized) }\end{array}$ & \\
\hline
\end{tabular}

The General Pre-Test was divided into a reading test and a writing test with a total of 15 words each. In the reading test, a word appeared at the center of the computer screen and the participant was asked to read it to the experimenter. In the writing test, the participant received a sheet of paper, a pencil, and an eraser and a screen without a visual stimulus was presented with the instruction "Write (word to be written)". Participants wrote the word on the sheet and let the experimenter know when they were finished. Throughout the General Pre-Test, the participant could correct the answer by erasing it as often as deemed necessary and could even return to the words that were already marked as finished.

The General Post-Test consisted of the presentation of tasks identical to those in the General Pre-Test; however, participants were given 76 words in the reading and 20 in the writing test. No consequence was programmed for the General Pre- or Post-Test.

Module 1 aimed to teach 51 simple and regular words comprised of two or three syllables. This module was divided
Data collection. The general procedure involved the following steps: (a) General reading and writing (dictation) Pre-Test; (b) teaching dictated words/syllables, printed words/syllables relations, and dictation tasks (CRMTS); (c) evaluation of reading and writing after each teaching unit (Unit Post-Test); and (d) General Post-Test. Table 2 shows Modules 1 and 2 steps. unit test (not computerized)

into four teaching units, these units being divided into steps, which taught three words each. The teaching steps were composed of matching-to-sample trials between dictated words and printed words, interspersed with dictation with constructed response (CRMTS) trials.

In the matching trials one word was dictated and the participant chose between two printed words presented as comparison stimuli, one corresponded to the dictated sample. These trials were based on the exclusion procedure (Dixon, 1977), aims at minimizing participant errors during the process. This means that the two comparison stimuli (written words) that appeared in each trial consisted in one new stimulus and one stimulus known to the participant (previously learned). Thus, the task of choosing according to the sample could be either to choose the new stimulus (exclusion trials) or to choose the known stimulus (novelty control trials). Each correct choice was followed by verbal praise. When errors occurred, the program presented a message indicating the 
error and a new screen, similar to that which resulted in the error, was presented as a new trial.

The teaching steps were also composed of dictation trials (CRMTS) presented after exclusion trials. In the dictation trials, the participant was asked to write the target word with moveable individual letters that appeared at the bottom of the computer screen and moved to the top of the screen when touched with the cursor. The participant could correct the written word by touching the letters again. Consequences were scheduled for correct responding, however, there were no programmed consequences for incorrect responses.

At the end of each teaching step, after 15 exclusion trials (five for each word taught in the step in question), 10 novelty control trials, and 6 CRMTS trials (two for each word taught in the step), a posttest was presented. In this test, the participant was requested to choose each one of the three words taught in that step, each in a different trial (total of three trials, one for the choice of each word), in which the three words appeared as comparison stimuli. If the performance of the participant was $100 \%$ correct, the Syllabic Training was presented. Scores lower than $100 \%$ led to the re-teaching of the whole words.

The purpose of the Syllabic Training was to put participant's behavior under control of minimal textual units of the target words. Each block of trials was conducted with syllables belonging to only one of the three words taught in that step. The trials were initiated with the choice of the figure corresponding to the entire word. Next, the matchingto-sample trials using the syllables of the target word were presented. The same exclusion and correction procedures indicated for the matching trials with whole words were used. The block of trials was programmed so that each syllable of the word in question was chosen three times. When $100 \%$ of correct responses occurred, the participant wrote the word in question using the individual syllables (dictation-CRMTS). If errors occurred, the participant repeated the matchingto-sample block, and then the whole word writing test was represented. Only three blocks of syllable selection were presented for each word and, if any errors persisted in the final test, the step was terminated.

After each teaching unit, a reading post-test of the target words taught in that unit was conducted. This test followed the same principle as the General Pre-test. When participants achieved $100 \%$ accuracy in this reading test, they performed a dictation test (writing test) of the target words. Otherwise, the participant had to repeat the steps related to the words read incorrectly. Then, the unit post-test was presented again.

The writing test was performed without computer support, similar to the General Pre-Test; however, after receiving a sheet of paper, a pencil, and an eraser, the instructions on the word to be written were presented by the experimenter. The instruction was repeated if the participant requested it, and he/she was allowed to erase and rewrite the word as often as deemed necessary and could also return to the words that had been finalized.
Data analysis. The results were analyzed in terms of performance in reading tasks from the Learning to read and write in small steps teaching objectives, performance in writing tasks, behavior that was only tested and that can be seen as a measure of the generalization effects from a procedure used in a controlled setting to new skills and new settings.

For this, analyses were made that resulted in: (a) percentage of correct reading responses; (b) percentage of correct writing responses (whole words); (c) percentage of correctly written bigrams (Hanna et al., 2004, Lee \& Sanderson, 1987); and (d) number of repetitions of the teaching units to obtain $100 \%$ accuracy in reading (criterion for passing from one unit to the next). The bigram analysis was used by Hanna et al. (2004) and Lee and Sanderson (1987) and allows a qualitative evaluation of the writing of the participants by analyzing the letters used and the position in which they appear in the word. For example: if the word cavalo was dictated, and the participant wrote cavlo, the bigram analysis would show that of the seven bigrams in the word cavalo (sets: space-c, c-a, a-v, v-a, a-1, l-o and o-space), in writing cavlo the participant correctly identified five of them (space-c, c-a, a-v, 1-o and o-space).

\section{Ethical Considerations}

The study was conducted with the approval of the Research Ethics Committee (REC) of the Universidade Estadual de Ciências da Saúde de Alagoas (UNCISAL) under protocol no. 975.

\section{Results and Discussion}

Figure 1 shows the percentage of correct reading and writing responses in the General Pre-Test in the post-tests after each teaching unit and in the General Post-Test of Module 1.

As it can be observed, there was an increase in the percentage of correct responses for whole words in reading and writing (dictation) tasks when compared to the performances in the General Pre-Test and in the other tests of the procedure. Overall, the scores in reading the target words were systematically higher than the scores in writing (dictation) the same words. These data follow the pattern shown in the literature of the area (de Rose et al., 1996; Hanna et al., 2004; Medeiros et al., 1997; Melchiori et al., 2000; Reis et al., 2009; Sella et al., 2010), which suggests that there seems to be no guarantee that the relations directly taught in the procedure, added to CRMTS tasks, will result in correct writing after the teaching of reading.

Specifically related to the reading tasks, the participants needed a variable number of exposures to the unit post-tests to meet the performance criterion: P1 and P3 achieved $100 \%$ accuracy on the first presentation of the post-tests while P2 and P4 needed to be exposed to repetitions of the teaching steps and the reading test, as illustrated in Figure 1. However, with each new teaching unit, fewer repetitions were necessary for $\mathrm{P} 4$ to achieve the $100 \%$ correct responses 
criterion. This may demonstrate the phenomenon of learning sets (learning to learn) (Harlow, 1949).

These data show that such procedures can function as extra tools to help youth and adult teachers of in the classroom. Because procedure implementation requires few repetitions of the teaching units, there is an acceleration in the learning to read process and consequently there may be an increase in student motivation who are enrolled in programs such as EJA. This increase in motivation can prevent, or at least reduce, the high dropout rates reported by Gentili (2003). Furthermore, as an extra resource to be used by the teacher, teaching procedures such as these can
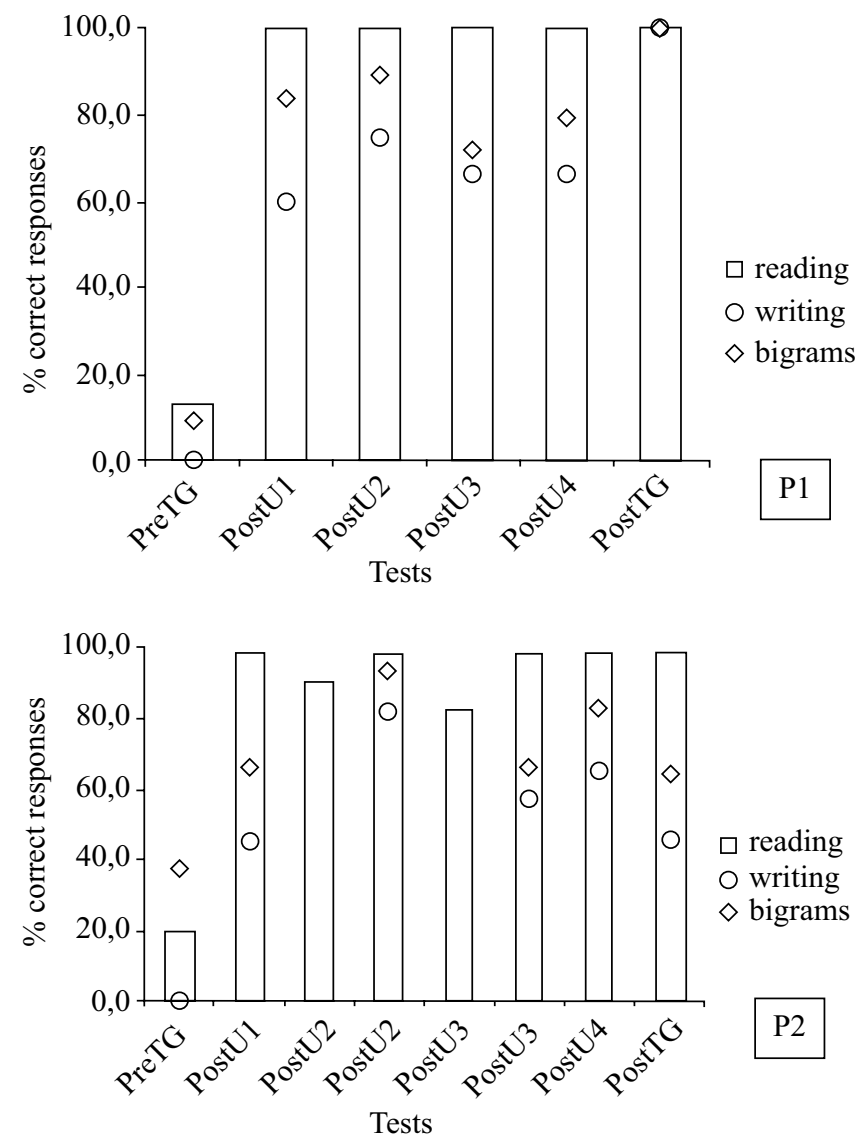

be programmed to work with any word (i.e., the teacher can individualize part of the educational program, teaching words that might be useful to students in their daily lives). This possibility of proximity between the content taught and the day-to-day of the students is highly desirable, as shown by Amparo (2012) and Oliveira (2007), for example.

Regarding the writing (dictation) tasks, Figure 1 shows that, unlike the reading performance, the increase in the unit post-test scores and in the General Post-Test was not consistent, presenting both intra- and inter-subject variability. Intra-subject variability was not observed for P3 who obtained similar results in all post-tests (unit and
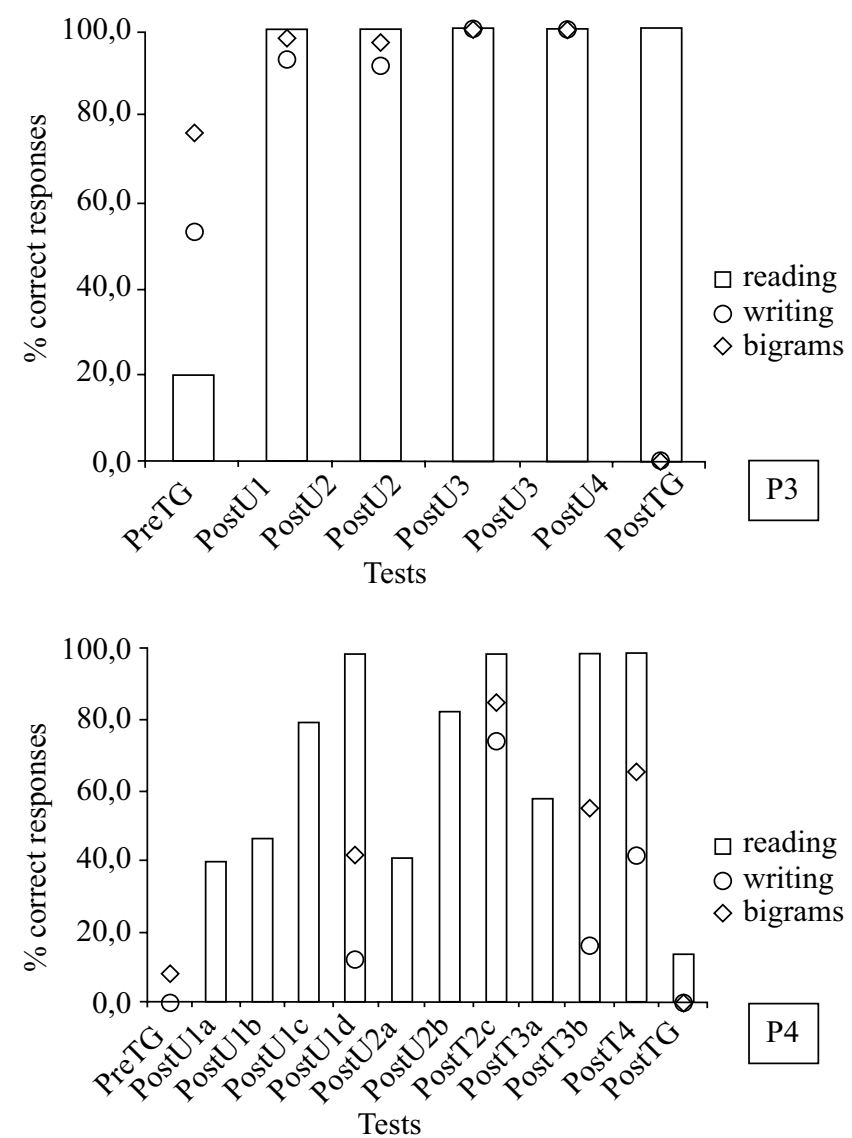

Figure 1. Percentage of correct reading and writing responses and bigrams in the general pre-test, the tests performed at the end of each teaching unit, and in the general post-test of teaching module 1.

general). For the other participants, the percentage of correct responses increased and decreased throughout the procedure. Regarding the inter-subject variability, it can be observed that there was no consistency in the percentage of correct responses in any of the unit post-tests. These data can contribute to the improvement of youth and adult teaching programs, as it shows that, although related, reading and writing repertoires need to be taught separately for the learning to be satisfactory. The planning of the work by educators, as suggested by Ribeiro (2006), should clearly include specific tasks so that writing (in the form of dictation and spontaneous writing) accompanies the development of reading skills.
After the completion of Study 1, Study 2 was carried out, which evaluated the effects of Module 2 from Learning to read and write in small steps curriculum (de Rose et al., 1996; de Souza et al., 2009) on complex and irregular words reading and writing. Simple words reading and writing skills were evaluated and participants obtained scores above $80 \%$ of correct responses. However, it was identified that they were not able to read or write words that contained Portuguese language difficulties. It is worth to note that Module 2 contained no Syllabic Training given the difficulty of separating words with such complexities into syllables. 


\section{Method - Study 2}

\section{Participants}

Study participants were three men and one woman (participant of Study 1), students of the public system EJA program in the State of Alagoas. The participants were aged between 28 years and 9 months and 46 years and 2 months at the beginning of the study and had rates between $0 \%$ (zero percent) and $52 \%$ (fifty-two percent) of correct reading in the General Pre-Test of the procedure (Table 3).

\section{Instruments}

Module 2 of the Learning to read and write in small steps curriculum (Rosa Filho et al., 1998) was used to teach complex Portuguese words. The data collection environment was exclusively the classroom provided by the school that the participants attended, as described in Study 1.

Table 3

Characterization of the Participants of Study 2, by Gender, Age, Performance in Reading and Writing of Whole Words in the Pre-Test, and Participation in Study 1

\begin{tabular}{lccccc}
\hline Participants & Gender & Age & $\begin{array}{c}\text { \% of Correct Reading } \\
\text { Responses }\end{array}$ & $\begin{array}{c}\text { \% Correct Writing } \\
\text { Responses }\end{array}$ & $\begin{array}{c}\text { Participation in } \\
\text { Study 1 }\end{array}$ \\
\hline P1 & F & 46 years and 2 months & 40 & 0 & Yes \\
P2 & M & 28 years and 9 months & 52 & 8 & No \\
P3 & M & 33 years and 9 months & 4 & 0 & No \\
P4 & M & 33 years & 0 & 32 & No \\
\hline
\end{tabular}

\section{Procedure}

Data collection. The general procedure involved the following steps: (a) reading and writing (dictation) General Pre-Test; (b) teaching dictated and printed word relations, interspersed with dictation-CRMTS trials; and (c) reading and writing (dictation) evaluation after each teaching unit (unit post-tests). Table 2 shows the steps of the procedure.

The General Pre-Test was computerized and aimed to evaluate participant's initial reading and writing repertoires. This test was divided into a reading and a writing test, with a total of 25 words each. Each new dictated word had at least one new Portuguese language difficulty, different from the difficulties in the previously dictated words. The tests were conducted exactly in the same way as they were in the same phase of Study 1.

The teaching procedure, as in Study 1, was divided into units that were divided into steps. Each set of five steps, four teaching and one test, formed a unit, and each of the three units taught a Portuguese language difficulty (e.g., ç, nh, lh). In each step, four words were taught through tasks that established relations between the printed and dictated words, totaling 48 words, 16 taught in each unit.

The teaching of the words, as in Study 1, was based on the exclusion procedure, with exclusion and "novelty control" trials. Correct responses were followed by praise and incorrect responses were followed by an error message and a new identical trial. Correct choices in the exclusion/novelty control trials were followed by a new trial, in which the participant had to write the word (dictation-CRMTS).

Performance tests were carried out at the end of each teaching step. In these tests, the participants had to write the target words (dictation-CRMTS) correctly: 100\% of correct responses were required for the participant to progress to the next step.
After each teaching unit a reading post-test was performed, which followed the same structure as the reading test in the General Pre-Test. The words presented in this reading test were the words learned during the unit in question. When the participants reached $100 \%$ of correct responses, they progressed to the next teaching unit and performed a dictation test, identical to Study 1, with the target words taught in this teaching phase. If the participants did not achieve the criterion of $100 \%$ of correct responses, they were asked to repeat the whole unit and given a new reading test.

Data analysis. The results were analyzed similarly to Study 1, for all the tests performed: (a) percentage of correct reading responses; (b) percentage of correct writing responses (whole words); (c) percentage of bigrams written correctly; and (d) number of repetitions of the teaching units to obtain $100 \%$ accuracy in the reading tasks (criterion for passage from one unit to the next).

\section{Ethical Considerations}

The study was conducted with the approval of RECUNCISAL also under protocol no. 975.

\section{Results and Discussion}

Figure 2 shows the percentage of correct responses in preand post-tests of each teaching unit regarding performance in reading and writing (whole words and bigrams) tasks. As in Study 1, there was an increase in the percentage of correct responses for whole words in the reading and writing tasks compared to the performances obtained in the pre-test and in the unit post-tests, with the reading of target words scores systematically higher than the writing scores. These data maintain the pattern shown in Study 1 and in the literature (de Rose et al., 1996; Hanna et al., 2004; Medeiros et al, 1997; Melchiori et al., 2000; Reis et al., 2009; Sella et al., 

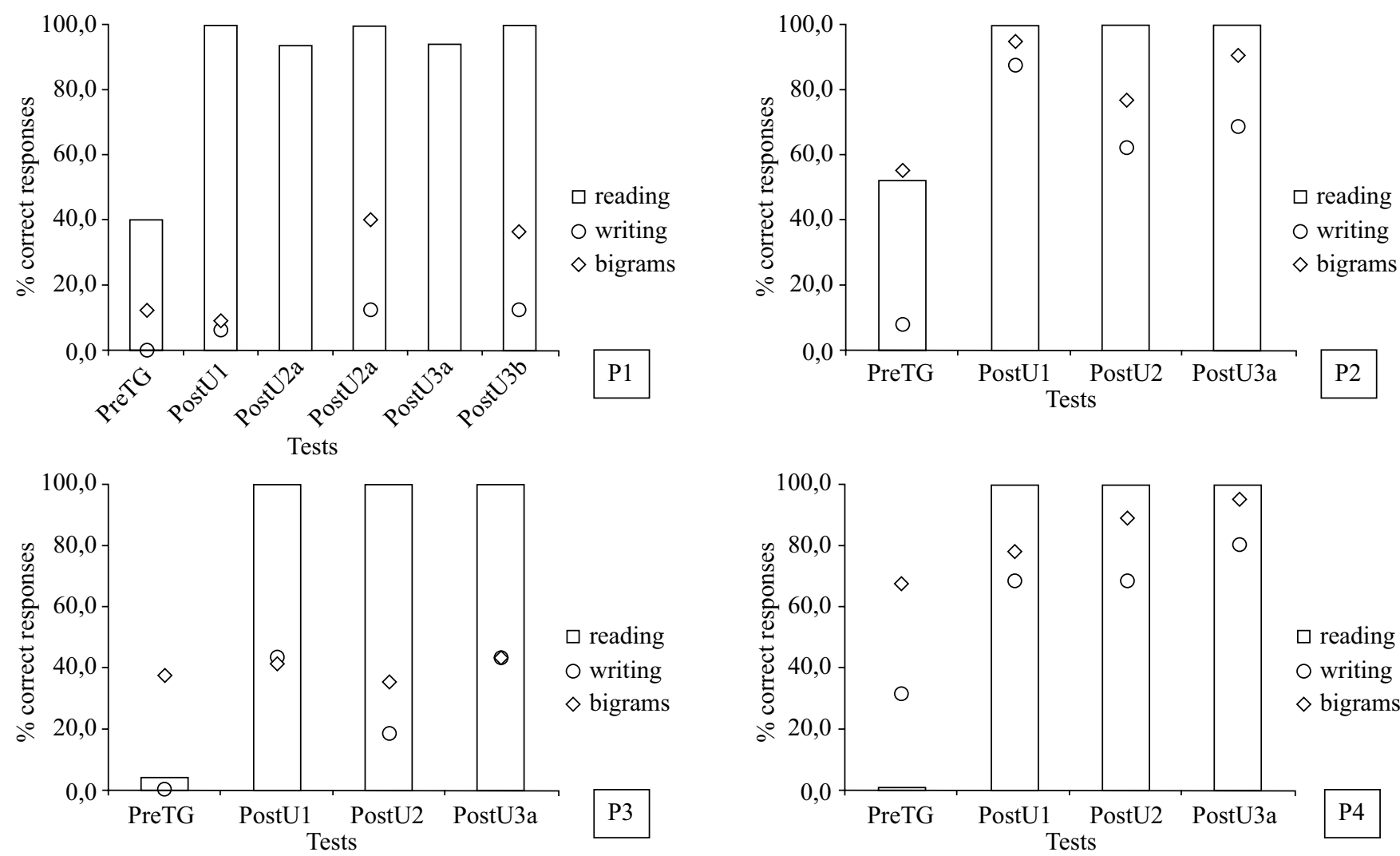

Figure 2. Percentage of correct reading and writing responses and bigrams in the general pre-test and post-tests performed at the end of each teaching unit of teaching module 2 .

2010). However, regarding the performance in writing tasks, the percentages of correct responses were more modest than in the first study and there were no tests in which $100 \%$ of the dictated words were spelled correctly by any of the participants. This decrease in performance may be due to two factors: (a) the target words in this study had Portuguese language difficulties and generally consisted of three syllables (and not two syllables as in Study 1) and/or (b) the syllabic training was not presented in Study 2. In the latter case, it is assumed that the presence of such training may have contributed to establish better control by relevant stimuli (minimal units) in Study 1.

Specifically in relation to the reading tasks, the percentage of correct responses in the unit post-tests soon reached $100 \%$ in the first exposures to the test. The only participant who needed more than one exposure in these tests was $\mathrm{P} 1$, who was exposed twice to the post-tests of Units 2 and 3 to meet criterion.

Finally, as also illustrated in Figure 2, inter-subject and intra-subject variability was observed in the writing (dictation) data in both the analysis of whole words and the analysis of bigrams, as in Study 1. These data again highlight the issue raised in the discussion of Study 1 that the repertoires of reading and writing, although related (Sidman, 1994), should be taught as independent repertoires (Skinner, 1957). These data raise the issue that in order to construct adequate and systematic planning, as suggested by Ribeiro (2006), it is necessary for the teacher to focus on the differences between teaching simple words and complex words of the Portuguese language. This is because, in general, the texts used in the classroom are composed of both types of words, which cannot be different in an adult education process. However, supporting the results obtained by Medeiros et al. (1997), the results showed that the degree of learning difficulty, especially regarding writing, is higher for the complex words. Therefore, the number of tasks performed in the classroom with these types of words should also be greater.

\section{Conclusion}

The results show that Modules 1 and 2 of the Learning to read and write in small steps curriculum can also be used in the adult population to teach reading. Therefore, this procedure can be used as an additional tool in teaching young people and adults to allow rapid and efficient progress in learning to read target words. This rapid learning can facilitate the teaching of other content, such as Mathematics or History, for example, since the learning of any discipline depends on reading with comprehension.

Furthermore, its programming possibilities allow teaching to be carefully and, if necessary, individually planned, taking into account students' daily activities in the classroom. This allows students to learn different words specifically related to their life context. Teaching may also 
prove advantageous because it starts from simple tasks (simple words) and moves toward complex tasks (complex words), avoiding constant mistakes during the learning process that could lead to loss of motivation and dropout.

In regards to the writing tasks, despite the overall improvement in performance, the results were less consistent, and further research should be carried out so that variables specific to writing performance can be investigated and incorporated into the procedure. It is important to have a more systematic verification of the effect that each teaching task used in the program (dictation-CRMTS and syllabic training) has on the writing repertoire. As noted in Study 1, the data seem to indicate that the syllabic training was not one of the critical variables for the emergence of writing, as the results regarding this behavior were lower than those obtained in reading. However, when this training was removed in Module 2, writing performance was even lower showing that the syllabic training would have been useful, at least to some extent, for the emergence of this repertoire. Therefore, further studies that can isolate the 'presence of Syllabic Training' variable could clarify this question.

Finally, it is necessary to highlight the limits of this work as, in the midst of a wide range of publications in the area of youth and adult literacy produced using many approaches, this work had a very specific purpose, namely, to investigate the most basic process of learning the soundtext correspondences that allow the decoding or recognition of words. This is the most basic of the components of competent reading, without which a person cannot read; however, in isolation, it does not address the goals of true reading competence with comprehension (Adams, 1998), nor literacy competence, as recommended by the literature of the area, briefly discussed in this text. The literature considers that youth and adult literacy should not only include content instruction, but also provide the possibility for learners to achieve autonomy through the appropriation of reading and writing, i.e., that through reading and writing they reveal themselves as subjects able to interpret the facts of the world (Andrade et al., 2009; Arroyo, 2007; Friedrich et al., 2010; Muenchen \& Auler, 2007; Ribeiro, 2006; Soares, 2008; Strelhow, 2010). Despite this limitation, it is hoped that the paper will contribute to the understanding of the basic acquisition process of this important requirement for the progress of the novice reader and, more broadly, that this contribution can favor the learning of these individuals in their daily contexts.

\section{References}

Adams, M. J. (1998). The three-cueing system. In J. Osborn, \& F. Lehr (Eds.), Literacy for all: Issues in teaching and learning (pp. 73-99). New York: Guilford.

Alves, K. R. S., Kato, O. M., Assis, G. J. A., \& Maranhão, C. M. A. (2007). Leitura recombinativa em pessoas com necessidades educacionais especiais: Análise do controle parcial pelas sílabas. Psicologia: Teoria e Pesquisa, 23(4), 387-398. doi:10.1590/S0102-37722007000400004
Andrade, E. R., Esteves, L. C. G., \& Oliveira, E. C. (2009). Composição social e percursos escolares dos sujeitos do ProJovem: Novos/velhos desafios para o campo da educação de jovens e adultos. Em Aberto, 22(82), 73-89.

Amparo, M. A. M. (2012). A infantilização do ensino na educação de jovens e adultos: Uma análise no município de Presidente Prudente. Boletim GEPEP, 1(1), 49-62.

Arroyo, M. G. (2007). Balanço da EJA: O que mudou nos modos de vida dos jovens-adultos populares?Revej@ Revista de Educação de Jovens e Adultos, 1(0), 5-19.

de Rose, J. C., de Souza, D. G., \& Hanna, E. S. (1996). Teaching reading and spelling: Exclusion and stimulus equivalence. Journal of Applied Behavior Analysis, 29(4), 451-469. doi:10.1901/jaba.1996.29-451

de Souza, D. G., \& de Rose, J. C. (2006). Desenvolvendo programas individualizados para o ensino de leitura. Acta Comportamentalia, 14(1), 77-98.

de Souza, D. G., de Rose, J. C., \& Domeniconi, C. (2009). Applying relational operants to reading and spelling. In R. A. Rehfeldt, \& Y. Barnes-Holmes (Eds.), Derived relational responding: Applications for learners with autism and other developmental disabilities: A progressive guide to change (pp. 171-207). Oakland, CA: New Harbinger.

de Souza, D. G., de Rose, J. C., Fonseca, M. L., \& Hanna, E. S. (1999). Stimulus control research and minimal units for reading. Experimental Analysis of Human Behavior Bulletin, 17(1), 20-23.

de Souza, D. G., de Rose, J. C., Faleiros, T. C., Bortoloti, R., Hanna, E. S., \& McIlvane, W. J. (2009). Teaching generative reading via recombination of minimal textual units: A legacy of verbal behavior to children in Brazil. Revista Internacional de Psicología y Terapia Psicológica, 9(1), 19-44.

Di Pierro, M. C., Joia, O., \& Ribeiro, V. M. (2001). Visões da educação de jovens e adultos no Brasil. Cadernos CEDES, 21(55), 58-77. doi:10.1590/S0101-32622001000300005

Dixon, L. S. (1977). The nature of control by spoken words over visual stimulus selection. Journal of the Experimental Analysis of Behavior, 27(3), 433-442. doi:10.1901/jeab.1977.27-433

Dube, W. V., McDonald, S. J., McIlvane, W. J., \& Mackay, H. A. (1991). Constructed-response matching to sample and spelling instruction. Journal of Applied Behavior Analysis, 24(2), 305-317. doi:10.1901/jaba.1991.24-305

França, R. A., Bandini, H. H. M., \& Bandini, C. S. M. (2011). Ensino de leitura e escrita para deficientes auditivos: $O$ uso conjunto de software de ensino e sistemas de frequência modulada. Unpublished report.

Friedrich, M., Benite, A. M. C., Benite, C. R. M., \& Pereira, V. S. (2010). Trajetória da escolarização de jovens e adultos no Brasil: De plataformas de governo a propostas pedagógicas esvaziadas. Ensaio: Avaliação e Políticas Públicas Educacionais, 18(67), 389-410. doi:10.1590/S0104-40362010000200011

Gentili, P. (2003). Educação de jovens e adultos. Nova Escola, XVIII (167), 35. 
Harlow, H. F. (1949). The formation of learning sets. PsychologicalReview, 56(1), 51-65.doi:10.1037/h0062474

Hanna, E. S., de Souza, D. G., de Rose, J. C., \& Fonseca, M. (2004). Effects of delayed constructed-response identity matching on spelling of dictated words. Journal of Applied Behavior Analysis, 37(2), 223-227. doi:10.1901/jaba.2004.37-223

Hübner, M. M. C., Gomes, R. C., \& McIlvane, W. (2009). Recombinative generalization in minimal verbal unitbased reading instruction for pre-reading children. Experimental Analysis of Human Behavior Bulletin, 27(1), 11-17.

Instituto Brasileiro de Geografia e Estatística. (2011). Pesquisa nacional por amostra de domicílios 2011. Retrieved from http://www.ibge.gov.br/home/estatistica/ populacao/trabalhoerendimento/pnad2011/default.shtm

Lee, V. L., \& Sanderson, G. M. (1987). Some contingencies of spelling. The Analysis of Verbal Behavior, 5, 1-13.

Medeiros, J. G., Monteiro, G., \& Silva, K. Z. (1997). O ensino da leitura e escrita a um sujeito adulto. Temas em Psicologia, 5(1), 65-78.

Melchiori, L. E., de Souza, D. G., \& de Rose, J. C. (2000). Reading, equivalence, and recombination of units: A replication with students with different learning histories. Journal of Applied Behavior Analysis, 33(1), 97-100. doi:10.1901/jaba.2000.33-97

Muenchen, C., \&Auler, D. (2007). Configurações curriculares mediante o enfoque CTS: Desafios a serem enfrentados na educação de jovens e adultos. Ciência \& Educação, 13(3), 421-434. doi:10.1590/S1516-73132007000300010

Oliveira,I.B.(2007).Reflexõesacercadaorganizaçãocurricular e das práticas pedagógicas na EJA. Educar em Revista, (29), 83-100. doi:10.1590/S0104-40602007000100007

Organização das Nações Unidas para a Educação, a Ciência e a Cultura. (2011). Programa da UNESCO no Brasil 2011-2012. Unidade de Publicações da Representação da UNESCO no Brasil: Brasília.

Paiva, J., Machado, M. M., \& Ireland, T. (2007). Educação de jovens e adultos: Uma memória contemporânea, 1996-2004. Edições MEC/UNESCO: Brasília.

Ribeiro, V. M. (2006, julho/agosto). Analfabetismo e alfabetismo funcional no Brasil. Boletim INAF, 6-8.

Reis, T. S., de Souza, D. G., \& de Rose, J. C. (2009). Avaliação de um programa para o ensino de leitura e escrita. Estudos em Avaliação Educacional, 20(44), 425-452.

Rosa Filho, A. B., de Rose, J. C. C., de Souza, D. G., Hanna, E. S., \& Fonseca, M. L. (1998). Aprendendo a ler e a escrever em pequenos passos [Computer software].

Sella, A. C., Bandini, C. S. M., Oliveira, L. R. B., \& Bandini, H. H. M.(2010). Teaching isolated words: Reading and its effects on writing skills. Unpublished report.

Soares, L. (2008). O educador de jovens e adultos e sua formação. Educação em Revista, (47), 83-100. doi:10.1590/S0102-46982008000100005
Sidman, M. (1994). Equivalence relations and behavior: A research story. Boston: Authors Cooperative.

Skinner, B. F. (1957). Verbal behavior. New York: AppletonCentury-Crofts.

Strelhow, T. B. (2010). Breve história sobre a educação de jovens e adultos no Brasil. Revista HISTEDBR On-line, 10(38), 49-59.

Stromer, R., \& Mackay, H. A. (1992). Delayed constructedresponse identity matching improves the spelling performance of students with mental retardation. Journal of Behavioral Education, 2(2), 139-157

Stromer, R., Mackay, H. A., Howell, S. R., McVay, A. A., \& Flusser, D. (1996). Teaching computer-based spelling to individuals with developmental and hearing disabilities: Transfer of stimulus control to writing tasks. Journal of Applied Behavior Analysis, 29(1), 25-42. doi:10.1901/jaba.1996.29-25

Carmen Silvia Motta Bandini is an Associate Professor at Universidade Estadual de Ciências da Saúde de Alagoas, and at the Centro Universitário CESMAC.

Heloisa Helena Motta Bandini is an Associate Professor at Universidade Estadual de Ciências da Saúde de Alagoas.

Ana Carolina Sella is a Postdoctoral Fellow at University of Nebraska Medical Center, Center for Autism Spectrum Disorders Omaha.

Deisy das Graças de Souza is a Full Professor at Universidade Federal de São Carlos.

Received: Apr. $26^{\text {th }}, 2012$

$1^{\text {st }}$ Revision: Mar. $3^{\text {rd }}, 2013$

Approved: Apr. 29 $9^{\text {th }}, 2013$

How to cite this article:

Bandini, C. S. M., Bandini, H. H. M., Sella, A. C., \& de Souza, D. G. (2014). Emergence of reading and writing in illiterate adults after matching-to-sample tasks. Paidéia (Ribeirão Preto), 24(57),75-84.doi:10.1590/1982-43272457201410 